\title{
British Geological Survey (BGS), Natural Environment Research Council, $U K$
}

BGS was established on July $11^{\text {th }} 1835$ as the Ordnance Geological Survey after William Buckland, Charles Lyell and Adam Sedgwick stated:

"we drew up a joint report in which we endeavoured to state fully our opinion as to the great advantages which must accrue from such an undertaking, not only as calculated to promote geological science, which alone would be sufficient object, but also as a work of great practical utility bearing on agriculture, mining, road making, the formation of canals and railroads and other branches of national industry."

The first director of the Survey was Henry Thomas de la Beche www.bgs.ac.uk/services/ $n g d c /$ archives and an act of parliament in 1845 gave the Survey powers to complete the survey of Great Britain and Ireland.

The core role of the BGS, and essentially of all of the world's geological surveys, has changed little since 1845 . We provide an upto-date view of the geological outcrop and subsurface of our nations, with the aim of enhancing economic development, providing secure supplies of mineral and energy resources, and underpinning living standards for the nation. This requires us to map, observe and model the landmass. This must be done in close association with government, private sector stakeholders and the universities, the latter being essential in providing robust testing of the data and models through research.

Various historical events and scientific discoveries have helped to define the role of the BGS in different eras. The former include the Industrial Revolution, two world wars and the development of an overseas geological survey - the first overseas assignment began in 1846 with a survey of the coalfields of Calcutta. These historical events were coupled to two scientific paradigm shifts: firstly the understanding of stratigraphical concepts in the earliest $19^{\text {th }}$ century and the preparation of the first useful geological maps; secondly, developing an understanding of plate tectonics from the 1960s to the present day.

To all of this we must add the global challenges that are now confronting us: population growth; climate change; resource security; environment and health. Geological surveys will play a key role in addressing all of these challenges, but to achieve this we must develop deeper partnerships with ecologists, sociologists, economists and the public, as our data is increasingly made available and is scrutinised in detail.

Governance: BGS is unusual for a geological survey in that it is not in a government ministry, but is part of a science research council - the Natural Environmental Research Council (NERC) www.nerc.ac.uk. As BGS Executive Director, I report to the Chief Executive of NERC who reports to Research Councils UK (RCUK) www.rcuk.ac.uk; they are in turn part of the UK Government Department of Business Skills and Innovation (BIS) www.bis.gov.uk. Thus, I only rarely talk to a government minister. However, the government knows who we are and we have a good relationship with the Government Chief Scientist's office www.bis.gov.uk/go-science.

BGS resources: BGS now employs about 650 full-time equivalent (FTE) staff, who are distributed across three main sites: the Keyworth Environmental Science Centre, our headquarters near Nottingham (about 420 FTEs); Murchison House on the Edinburgh University Campus in Scotland (about 150 FTEs); and Wallingford, near Oxford, where about 30 FTE hydrogeologists are located alongside the Centre for Ecology and Hydrology which is also part of NERC. We have small offices in the Natural History Museum, London and in Cardiff, Wales. We also run the Geological Survey of Northern Ireland (GSNI) under a UK government contract www.bgs.ac.uk/gsni/.

BGS annual funding is about $£ 50$ million (about $\$ 80$ million US) and half of this comes from NERC as a baseline amount and the other half is competitively won income from research grants, government grants and the private sector. The trend in government and research council funding is downwards with a consequent increased need for competitively won funds in the future.

Traditionally, BGS always had 50 or so scientists based overseas, and while this is still the case, we have recently launched a limited company (BGS international BGSi www.bgsinternational.co.uk/) to enable more effective working overseas. We have also sold part of our geochemistry facilities to Panalytical www.panalytical.com who will remain on site. We will increasingly open up the BGS site in Keyworth as a hub for environmental business and we may select other parts of BGS to be spin-out companies as they develop and mature commercially.

The BGS business model involves three principal components: a geosciences research institute; geosciences information and surveying; geosciences commercial services. All of these overlap and our staff may be asked to work in each area on a monthto-month basis or even on the same day. Figure 1 provides a summary of how these three components impact on BGS science.

Strategy: BGS will develop a stronger science base through more concrete partnerships with other UK and international universities, institutes, geological surveys, and industry. In recent years BGS has set up joint BGS-University centres in carbon capture and storage, strategic minerals, and environmental sustainability. BGS is also closely linked with universities through more than $60 \mathrm{PhD}$ projects. We have a rewarding collaboration with our neighbouring surveys in the north-west of Europe. The current focus is on a tectono-stratigraphical atlas of the northern North Atlantic which is co-funded by nine surveys and numerous oil and gas companies. We are also developing an ECfunded project on urban geology.

A second strategic direction has been the development of more openly available data through web services and "apps" such as iGeology www.bgs.ac.uk/igeology and mySoil www.bgs.ac.uk/mysoil. We have moved from paper production of geological maps to the development of fully downloadable digital geological maps, with a focus on making a 3D geological map of the UK. In future our mapping to underpin the UK geological 3D map will have less emphasis on baseline surveys but will focus on the surface deposits onshore, and offshore through MAREMAP www.noc.soton.ac.uk/ shmg/maremap. Responsive surveying will concentrate on the development of infrastructure such as the HighSpeed2 rail link www.hs2.org.uk/ which will join London, Birmingham and points north. 


\begin{tabular}{|c|c|c|c|c|c|}
\hline Role & Task & BGS UK infrastructure & BGS global science & $\begin{array}{l}\text { BGS natural hazards } \\
\text { (magnetic field) }\end{array}$ & $\begin{array}{l}\text { BGS marine } \\
\text { geoscience }\end{array}$ \\
\hline $\begin{array}{l}\text { Geoscience } \\
\text { information } \\
\text { and } \\
\text { surveying }\end{array}$ & $\begin{array}{l}\text { Geological, } \\
\text { geophysical } \\
\text { and } \\
\text { geochemical } \\
\text { survey data } \\
\text { and } \\
\text { information for } \\
\text { decision } \\
\text { making }\end{array}$ & $\begin{array}{l}\text { Detailed geological } \\
\text { architecture of the zone } \\
\text { of human interest in the } \\
\text { UK }\end{array}$ & $\begin{array}{l}\text { International mapping, } \\
\text { information resource } \\
\text { and training }\end{array}$ & $\begin{array}{l}\text { Monitoring of the local to } \\
\text { global field }\end{array}$ & $\begin{array}{l}\text { Survey of the subsurface } \\
\text { of the UK shelf. } \\
\text { Integration with sea-floor } \\
\text { habitats. } \\
\text { MAREMAP } \\
\text { Marine Environmental } \\
\text { Mapping Programme }\end{array}$ \\
\hline $\begin{array}{l}\text { Geoscience } \\
\text { research } \\
\text { institute }\end{array}$ & $\begin{array}{l}\text { Laboratory } \\
\text { and field } \\
\text { infrastructure, } \\
\text { quantitative } \\
\text { conceptual } \\
\text { models \& } \\
\text { process } \\
\text { models }\end{array}$ & $\begin{array}{l}\text { Monitoring shallow } \\
\text { geohazards and risks } \\
\text { including groundwater }\end{array}$ & $\begin{array}{l}\text { China \& India CCS } \\
\text { Montserrat } \\
\text { monitoring/research, } \\
\text { strategic minerals } \\
\text { research }\end{array}$ & $\begin{array}{l}\text { Global magnetic field } \\
\text { models }\end{array}$ & $\begin{array}{l}\text { Scientific research } \\
\text { drilling. European } \\
\text { Science Operator for } \\
\text { ECORD/IODP }\end{array}$ \\
\hline $\begin{array}{l}\text { Niche } \\
\text { industry }\end{array}$ & $\begin{array}{l}\text { Resource } \\
\text { optimisation, } \\
\text { market } \\
\text { analysis, } \\
\text { risk analysis, } \\
\text { scenario } \\
\text { planning }\end{array}$ & $\begin{array}{l}\text { Safe ground installation } \\
\text { for renewable energy } \\
\text { development }\end{array}$ & $\begin{array}{l}\text { BGS International } \\
\text { spinout }\end{array}$ & $\begin{array}{l}\text { Interpolation in-field } \\
\text { Referencing IFR for } \\
\text { drilling }\end{array}$ & $\begin{array}{l}\text { Tectonic atlas with nine } \\
\text { surveys and } 12 \text { industrial } \\
\text { partners }\end{array}$ \\
\hline
\end{tabular}

Figure 1

The science deliverable: Our 3D geoscience mapping will be developed into a quantitative conceptual geological model, process models and predictions, in order to allow us to provide scenarios and forecasts for environmental impacts and resource security.

The hard facts about the future: There is no doubt that the role of a survey in underpinning the economic development of the subsurface of our nations is essential. In the UK all publicly funded bodies are increasingly under pressure to define their impact on creation of wealth and on improving living standards. The baseline publicly funded part of BGS will be cut by as much as 20 per cent over the next three to five years. We are being encouraged to work with research partners in winning research grants, with the private sector co-funding geosciences research. We feel we can achieve this and maintain, if not grow, the total BGS budget and staff complement, but we will need to be even more flexible in managing our research priorities. In the UK these will increasingly be the global challenges identified earlier in this paper and will require research funding partnerships and joint ventures.

The rapid evolution in digital technology will change the way we do environmental and geological science. Geological surveys produce high-quality data and make it available, both free and in a charged-for mode. Surveys will be increasingly encouraged to provide their baseline data for free and will need to develop models for charging for high-quality research-generated products. Movements in Europe to create a single European database through projects such as OneGeologyEurope www.onegeologyeurope.eu or globally through OneGeology www.onegeology.org should become more common. However, such data mining may undermine the very raison d'être of a Survey, thus forcing Surveys towards more high-end data products and specialised research.

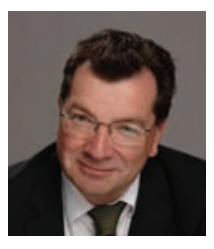

Professor John Ludden is currently the Executive Director of the British Geological Survey and serves on the Executive Committee of the Natural Environment Research Council, UK. He is also a Research Director (Classe exceptionnelle) of the Centre National de Recherche Scientifique (CNRS) where he was Associate Director for Earth Sciences and also at the Institut de Physique du Globe, Paris. Before moving to France in 1995 he was professor of geochemistry at the University of Montreal and worked with Woods Hole Oceanographic Institution in the USA. He holds a doctorate in igneous petrology from the University of Manchester, UK. He has served as the President of the European Geosciences Union and of EuroGeosurveys. He is a Visiting Professor at the Universities of Oxford and Leicester in the UK and an International Member of the Russian Academy of Sciences. 